NBER WORKING PAPER SERIES

\title{
LONG TERM EFFECTS OF CASH TRANSFER PROGRAMS IN COLOMBIA
}

\author{
Orazio Attanasio \\ Lina Cardona Sosa \\ Carlos Medina \\ Costas Meghir \\ Christian Manuel Posso-Suárez \\ Working Paper 29056 \\ http://www.nber.org/papers/w29056
}

\author{
NATIONAL BUREAU OF ECONOMIC RESEARCH \\ 1050 Massachusetts Avenue \\ Cambridge, MA 02138 \\ July 2021
}

We are grateful to the Metropolitan Police of Medellín for providing us access to all criminal data, to the DNP for providing us access to the SISBEN datasets, to Minister of education for providing us access to SPADIES, to the secretary of education of Medellin for proving us access to education records, and to the DPS for providing us access to the Familias en Acción administrative data. Manuela Cardona-Badillo, Gabriel Suarez, Sara Londoño, Silvia Granados, Estefania Saravia and Laura Prada provided excellent research assistance. The opinions expressed herein belong to the authors and do not necessarily reflect the views of Banco de la República or its Board of Directors. Costas Meghir is grateful to the Cowles foundation and to the ISPS at Yale for financial support. All errors and opinions are our own. The views expressed herein are those of the authors and do not necessarily reflect the views of the National Bureau of Economic Research.

NBER working papers are circulated for discussion and comment purposes. They have not been peer-reviewed or been subject to the review by the NBER Board of Directors that accompanies official NBER publications.

(C) 2021 by Orazio Attanasio, Lina Cardona Sosa, Carlos Medina, Costas Meghir, and Christian Manuel Posso-Suárez. All rights reserved. Short sections of text, not to exceed two paragraphs, may be quoted without explicit permission provided that full credit, including $\odot$ notice, is given to the source. 
Long Term Effects of Cash Transfer Programs in Colombia

Orazio Attanasio, Lina Cardona Sosa, Carlos Medina, Costas Meghir, and Christian Manuel

Posso-Suárez

NBER Working Paper No. 29056

July 2021

JEL No. D04,I23,I28,I31,J13,K42

\title{
ABSTRACT
}

Conditional Cash transfer (CCT) programs have been shown to have positive effects on a variety of outcomes including education, consumption and health visits, amongst others. We estimate the long-run impacts of the urban version of Familias en Acción, the Colombian CCT program on crime, teenage pregnancy, high school dropout and college enrollment using a Regression Discontinuity design on administrative data. ITT estimates show a reduction on arrest rates of $2.7 \mathrm{pp}$ for men and a reduction on teenage pregnancy of $2.3 \mathrm{pp}$ for women. High school dropout rates were reduced by 5.8pp and college enrollment was increased by $1.7 \mathrm{pp}$ for men.

\author{
Orazio Attanasio \\ Department of Economics \\ Yale University \\ 37 Hillhouse Avenue \\ New Haven, CT 06511 \\ and Institute for Fiscal Studies, \\ FAIR, BREAD and CEPR \\ and also NBER \\ orazio.attanasio@yale.edu \\ Lina Cardona Sosa \\ World Bank \\ 1818 H St NW \\ Washington, DC 20433 \\ lcardonasosa@worldbank.org \\ Carlos Medina \\ Medellín Branch \\ Banco de la República Calle \\ 50 \# 50-21 \\ Piso 2 Medellín \\ Colombia \\ cmedindu@banrep.gov.co
}

\author{
Costas Meghir \\ Department of Economics \\ Yale University \\ 37 Hillhouse Avenue New \\ Haven, CT 06511 \\ and IZA \\ and also NBER \\ c.meghir@yale.edu \\ Christian Manuel Posso-Suárez \\ Medellín Branch \\ Banco de la República de Colombia \\ Calle 50 \# 50-21 \\ Piso 2 Medellín \\ Colombia \\ cpossosu@banrep.gov.co
}




\section{Introduction}

Welfare programs are often designed to address the immediate needs arising from poverty, offering insurance and supporting families through periods of low income. Ever since the 1990's conditional cash transfers have become particularly popular as a way of achieving multiple goals at once: alleviating poverty and shifting household behavior in ways that may confer long-term benefits. For example, Progresa $a^{2}$ in Mexico was offered conditional on children attending school and mothers obtaining health checks. The result was a substantial improvement in schooling attendance (see Schultz, 2004; Attanasio, Meghir and Santiago, 2011; Todd and Wolpin, 2006) as well as multiple other benefits direct or indirect (see for example, Angelucci and De Giorgi, 2009, Attanasio and Pastorino, 2020). ${ }^{3}$

Since then, many other countries have implemented similar programs, including Colombia, where Familias en Acción (FeA) was designed to resemble Progresa closely. An important question is whether these programs have long lasting effects beyond the specific outcomes they target and beyond the period in which they are received by the beneficiary households. Answering this question and considering a variety of important long-term outcomes is central to understanding how welfare programs can be used in the fight against poverty and can shift the debate from the immediate questions of short-run benefits and incentive effects to the longer run perspective of improving opportunities and intergenerational outcomes. This question has been asked before in a number of contexts and the results overall indicate that welfare programs can and do have longer term effects on multiple important outcomes. For example, Hoynes, Schanzenbach and Almond (2016) consider the impact of food stamps on child health and mothers economic self-sufficiency, while Almond, Hoynes and Schanzenbach (2011) find positive impacts of food stamps available to pregnant women on the birthweight of their children. Deshpande and Mueller-Smith (2021) consider the impact of Supplemental Security Income awarded to youth with disabilities on crime in the US. Recently, Machado et al (2021) look at the impact of Bolsa Familia, a large cash transfer program in Brazil and find a substantial reduction in the suicide rate attributed to the program.

\footnotetext{
${ }^{2}$ Later renamed as Oportunidades and Prospera.

${ }^{3}$ There is also an active debate about the relative merits of cash versus in-kind transfers. Cunha (2014) and Cunha et al. (2019) look at the differential impact of in-kind vs cash transfers in rural Mexico, while Banerjee et al. (2021) compare food stamps to in-kind transfers of food in Indonesia. Moreover, the general equilibrium effects of cash transfer (on prices or on transfers between different households) can be different and substantial than those of in-kind transfers. (See, for instance, Egger et al. (2019) for a large unconditional cash transfer program in rural Kenya and Filmer et al. (2018) for a program in the Philippines).
} 
This paper is the first attempt to evaluate the long-term impacts of Familias en Accion $(\mathrm{Fe} A)$, a major welfare program typical of many in developing countries and which has been in place since 2002, on a broad set of outcomes using high quality administrative data. These data present a unique opportunity to examine some of the questions above both because the excellent administrative data provide large samples and accurate measurement of important outcomes and because, in the Colombian context, the eligibility to the specific program we consider is driven by a single index constructed for all households and with a well-defined eligibility cutoff. We consider three important outcomes for the young people who were children in the families eligible for this welfare program: crime, teenage pregnancy and education (including higher education). All three are central to life-cycle outcomes: being involved in crime leads to numerous adverse outcomes, including incarceration, lower involvement with the labor market and danger to life amongst others; teenage pregnancy can have negative health implications for the mother (depending on age), prevents women from completing education and launching a labor market career and can also lead to adverse outcomes for the resulting children because of inadequate parenting and resources; finally, improved education results in well-documented improvements in employment opportunities and earnings. None of these outcomes are directly targeted by the conditionalities of the program.

The impacts of $F e A$ have been studied in several papers, including Attanasio et al., (2010) who consider educational outcomes in the early rural version of the program and Attanasio, Oppedisano and Vera-Hernandez (2015) who demonstrate a 50\% increase in health visits for children as a result of the program. However, this is the first attempt to evaluate important longer-term impacts that have the potential to broaden the appeal of such programs. At the same time, we add evidence that such welfare programs are key elements for reducing poverty in a structural fashion by improving opportunities and outcomes for youth. ${ }^{4}$

Our data is obtained by linking various administrative data sets, including the SISBEN data that defines eligibility for every individual together with various administrative records on crime, births, and education. Our study focuses on Medellin where we have been allowed to link

\footnotetext{
${ }^{4}$ Evidence from the urban expansion shows an increase in the number of years of education between 4 and 8 percentage points (Villa, 2018 and Baez \& Camacho, (2011). Besides the targeted effects of the program, there is evidence of effects on a broader set of outcomes including on access to the formal financial sector, health, nutrition, domestic violence, female empowerment (Cardona and Medina, 2017; Attanasio et al., 2010; Attanasio and Mesnard, 2006; Barrientos et al., 2013; DNP, 2008; Núñez et al., 2011). Effects on fertility are negligible and evidence of effects on adults' labor supply is not conclusive (Barrientos et al,, 2013; Fiszbein et al., 2009; and Núñez et al., 2011). Molina-Millan, et al. (2016) have reviewed the literature on the long-term impacts of $\mathrm{Fe} A$.
} 
all the necessary administrative data. Medellin is the second largest city in Colombia with a population of about 2.5 million people. It thus offers a well-suited context for our study.

Our findings offer strong evidence of broad beneficial effects for these programs. Specifically, for the sample of men, we find a substantial reduction in crime: intent to treat estimates (ITT) indicate a reduction of arrest rates by 2.7 percentage points (pp), from a basis of $6.2 \%$ in the control sample. For women, we find a reduction in teenage pregnancy by $2.3 \mathrm{pp}$ from a control average of $8.5 \%$. For both men and women, we find a 5.8pp reduction in high school dropout rates, from basis of $61 \%$ and $50 \%$ respectively in the control sample. Finally, for the male sample, we find an increase in college enrolment of $1.7 \mathrm{pp}$ from a basis of $11 \%$. Accounting for treatment non-compliance we find that the LATE effects are considerably larger. The results are remarkable, particularly if one considers that most of the families have ceased to receive the transfer several years before the crime outcomes were observed, implying a strong long-term effect. Whether this is because of the increased schooling or because of other improvements in the family environment due to increased resources (or both) is an important research question that cannot be identified with the current research design. Simple mediation analysis suggests that increased schooling can only explain a quarter of the effect.

Whatever the mechanisms that might underlie these results, they are the first estimates of long run effects of CCT in urban contexts and they provide strong support for the broader role of these programs in improving long-run outcomes and mitigating the effects of poverty.

The rest of the paper is organized as follows. In Section 2, we describe the FeA program. In Section 3, we give details of the data we use in this paper. Section 4 provides a discussion of the econometric approach we use. Section 5 presents the results of the analysis and Section 6 concludes.

\section{The Familias en Acción program}

Familias en Acción is a conditional cash transfer program implemented in Colombia as a response to the economic crisis suffered in the late nineties. It provides a monetary transfer to low-income families conditional on children school attendance. The program was first implemented in 2002 and was initially targeted to people living in rural areas. In 2007 it was expanded to urban areas ${ }^{5}$. $\mathrm{Fe} A$ is targeted to the $20 \%$ poorest households in the country. The main objective of the

\footnotetext{
${ }^{5}$ National Advisory Board of Economic and Social Policy (CONPES) document No. 3472 of 2007.
} 
program has been to improve health and nutrition of children younger than 7 years old through subsidies, and to promote human capital accumulation for children aged 7 to 17 by transferring cash to their household conditional on regular school attendance (see Attanasio, Battistin \& Mesnard, 2012).

Eligibility for most social programs in Colombia is determined through proxy means testing. A single score is produced by the System for the Identification of Potential Beneficiaries of Social Programs (SISBEN) as a function of various household characteristics including demographics, income, economic activity, assets, sanitation and housing quality amongst others. The assigned score lies between zero and one hundred with lower numbers reflecting a greater degree of vulnerability. During the urban expansion of $\mathrm{Fe} A$, the government defined eligibility based on an updated version of the index (SISBEN-II), which was first introduced in 2005. To be eligible for $\mathrm{Fe} A$, the household had to satisfy the following requirements: (i) either to score 11 or less in SISBEN-II, or have been displaced from the civil war, or be part of a minority group; and (ii) to have children between 7 and 17 years of age attending school regularly or to have children younger than 7 years old attending health and nutritional checkups.

As shown in Table 1, FeA, is made of two types of subsidies; the health and nutritional subsidy targeted to households with children aged 0 to 6 ; the educational subsidy targeted to households with children aged 7 to 17 . While the first subsidy is conditional on attending health and nutrition checkups, the second subsidy is conditional on children attending $80 \%$ of school days. The amount of the subsidy varied between USD 7 and USD 20 per month depending on the grade the student was enrolled to (see Table 1). Subsidies are per child and thus combined.

Table 1. Financial subsidies in Familias en Acción

\begin{tabular}{clcc}
\hline & & $\begin{array}{c}\text { Monthly subsidy } \\
\text { (COP) }\end{array}$ \\
\hline \hline Nutrition & $0-6$ years old & $\$$ & $50,000.00$ \\
\hline \multirow{5}{*}{ Education } & Grades 2nd - 5th & $\$$ & $15,000.00$ \\
& Grades 6th - 8th & $\$$ & $25,000.00$ \\
& Grades 9th - 10th & $\$$ & $35,000.00$ \\
& Grade 11 & $\$$ & $40,000.00$ \\
\hline
\end{tabular}

Source: DNP (2010). Households with children 0-6 receiving the nutritional subsidy and with older children in education will also receive the education subsidy. In December $31^{\text {st }}$ of 2009 the exchange rate COP/USD was 2,044 per 1 USD. 


\section{Data and empirical approach}

In this section, we describe the data we use in the analysis and the empirical approach we use to identify the long run effects of $\mathrm{Fe} A$. We also provide evidence in support of our identifying assumptions.

\section{a. Data description}

We restrict the analysis to the city of Medellin and use the administrative records of program beneficiaries of the urban expansion in 2007. The data allows individual identification, entry date into the program and information such as age, gender and level of education.

The second dataset is SISBEN-II. It initially classified households into six different levels based on a score ranging between 0 and 100. Level one comprises the most disadvantaged households (Bottia, Cardona-Sosa and Medina, 2012). The scores were computed based on a survey of low-income households ${ }^{6}$ which contains socio economic information of the household members. Those households who were classified in the first two levels of SISBEN-II (or having a score of 11 or less) were eligible for the urban version of the CCT program in 2007. This data contains demographic information for eligible and non-eligible individuals. By merging the administrative records of the program with the SISBEN data, we can identify beneficiaries and non-beneficiaries and we are able to control for individual's background. The program was launched in March 2007 which is the date we define as baseline. We restrict the sample to families with children aged between 7 and 17 in 2007. These children are old enough to observe meaningful long-term outcomes for them by 2015, which is the time when we can link to relevant administrative data.

This data is merged with four additional datasets. The first one is the census of all the arrests that took place in Medellin between 2002 and 2015 from the Judicial Research Unit of the Metropolitan Police of Medellin. ${ }^{7}$ The information includes date and place of arrest, type of crime (e.g., violence, property and drug-related crimes), and individual information such as age and marital status. ${ }^{8}$ Second, we use information from the Vital Statistics Records of Medellin

\footnotetext{
${ }^{6}$ SISBEN surveyed around $76 \%$ of Colombian population.

${ }^{7}$ SIJIN is the acronym in Spanish.

${ }^{8}$ It is important to point out that the data used in this study corresponds to individuals' arrest and not to actual crime which might not be the same. In fact, one could be concern that changes in individual outcomes (such as
} 
between 2007 and 2016. It includes detailed information of all pregnancies, date and type of birth, and birth outcomes. Third, we use the school enrollment records of Medellín (Matricula en Linea) which provides annual information on individual grades and type of institution attended (e.g., public or private) up to 2017. Finally, we track higher education enrollment using the System for Dropout Prevention and Analysis in Higher Education Institutions (SPADIES by its acronym in Spanish), covering from 2006 to 2016.

\section{b. Empirical approach}

Our identification strategy exploits the assignment rule of the program which selects as beneficiaries, families scoring 11 or less in SISBEN-II. This creates a discontinuity on the probability of being a beneficiary of the program as a function of the score, allowing us to use a regression discontinuity approach or RDD (Thistlethwaite \& Campbell, 1960, and Imbens and Lemieux, 2008). Under this set up, households on both sides of the eligibility threshold are statistically similar in their characteristics, except for their eligibility for the program. The causal effect of the intervention can then be identified from comparing individuals who are just below and just above the eligibility cutoff. Hence, a discontinuity in any of the outcomes (e.g., being arrested, being pregnant, attend higher education) at the cutoff would be interpreted as an effect of the program.

Due to budget restrictions, frictions in the procedure of targeting individuals and maybe unofficial practices, not all eligible households satisfying the required conditionalities and scoring 11 or less in SISBEN-II received the program. Similarly, some (very few) households scoring above the eligibility threshold ended up receiving the benefit. This leads us to use a fuzzy design (Van der Klaauw, 2002 and Hahn, Todd \& Van der Klaauw, 2001). In what follows, we report the ITT estimates, based on potential eligibility implied by the score and the Local Average Treatment effect (LATE) reflecting the impact on compliers.

We implement the non-parametric robust bias-corrected estimator proposed in Calonico, Cattaneo, \& Titiunik (2014a, 2014b) for both, the ITT and LATE. We use the optimal

education) might affect the arrest rates and not the criminal behavior. Nevertheless, Lochner and Moretti (2004), using a rich set of controls, including cognitive measures have found for a previous study that the effects of education on crime are measurably similar for self-report data on offenses and for arrest rates. 
bandwidth computed for each of the subsamples used in each estimation. ${ }^{9}$ The results are robust to alternative bandwidths and parametric methods (2SLS). ${ }^{10}$

\section{c. Robustness Tests}

The identifying assumptions of the RDD approach include, first, that the probability of being treated changes discontinuously at the cutoff of the forcing variable (SISBEN-II score); second, that all other individual characteristics change smoothly around that cutoff. Figure 1 provides evidence of how program participation rates change discontinuously at the score of 11 in SISBEN-II. It shows the fit of the score on each side of the eligibility threshold using kernelweighted local polynomials. The size of the circles in the figure is proportional to the number of observations in that cell.

Table 2. First Stage estimates of the effect of SISBEN-based eligibility on FeA takeup

\begin{tabular}{lcccccccccc} 
& \multicolumn{3}{c}{ All sample } & \multicolumn{3}{c}{ Between 7 to 17 years old } & \multicolumn{3}{c}{ Over 17 years old } \\
& All & Women & Men & All & Women & Men & All & Women & Men \\
& $(1)$ & $(2)$ & $(3)$ & $(4)$ & $(5)$ & $(6)$ & $(7)$ & $(8)$ & $(9)$ \\
\hline \hline Coefficient & $0.217^{* * *}$ & $0.266^{* * *}$ & $0.162^{* * *}$ & $0.313^{* * *}$ & $0.309^{* * *}$ & $0.317^{* * *}$ & $0.164^{* * *}$ & $0.245^{* * *}$ & $0.069^{* * *}$ \\
Std. Error & $(0.010)$ & $(0.013)$ & $(0.009)$ & $(0.017)$ & $(0.019)$ & $(0.017)$ & $(0.008)$ & $(0.013)$ & $(0.006)$ \\
Observations & 486,844 & 262,309 & 224,535 & 163,247 & 80,600 & 82,647 & 323,597 & 181,709 & 141,888 \\
\hline Control Mean & 0.006 & 0.007 & 0.004 & 0.010 & 0.010 & 0.010 & 0.004 & 0.006 & 0.001 \\
\hline
\end{tabular}

Notes: *** Significant at the 1 percent level. ${ }^{* *}$ Significant at the 5 percent level. * Significant at the 10 percent level. The variance-covariance matrix is estimated using cluster-robust plug-in residuals variance estimator with the degrees-of-freedom as weights. We use an MSE-optimal bandwidth selector (below and above the cutoff) for the $\mathrm{RD}$ treatment effect estimator. The bandwidth is chosen by cross-validation. The local-polynomial is constructed using a triangular kernel function. The number of observations reported in the table correspond to the total sample size for that regression. The number of effective observations used depends on the optimal bandwidth.

Table 2 supports the previous finding. It shows the results of the effects of the eligibility rule on the likelihood of participating into the program. These estimates support our

\footnotetext{
${ }^{9}$ Men and women who were between 7 and 17 years old and older than 17 years old at baseline. We use triangular kernel-weighted local polynomial of degree 2 . We control for gender, education, age, household head characteristics (age and education), home ownership, type of dwelling, stratum, utilities (gas, sewerage, aqueduct) and crime at baseline. Standard errors are clustered using the running variables similar to Lee et al., (2008). Results are robust to other polynomials, kernels, bandwidths and parametric methods.

${ }^{10}$ We estimate the effects using several bandwidths and the results remain the same. For the parametric approach, we use 2SLS where we instrument the treatment (being $F e A$ beneficiary) with an indicator of being in the eligibility range of the SISBEN score.
} 
identification strategy: scoring below the eligibility threshold increases the probability of being a program beneficiary by about $21 \mathrm{pp}$ for the whole sample, which is significant at any conventional levels. For the subsample of young individuals between 7 and 17 years old, the estimate is about $32 \mathrm{pp}$, with no significant difference with respect to the gender of the child for this group. These estimates are robust to alternative methods and score intervals.

\section{Figure 1. Evidence on the Research Design}

Panel A. First stage: Probability of receiving FeA

Panel B. Manipulation test
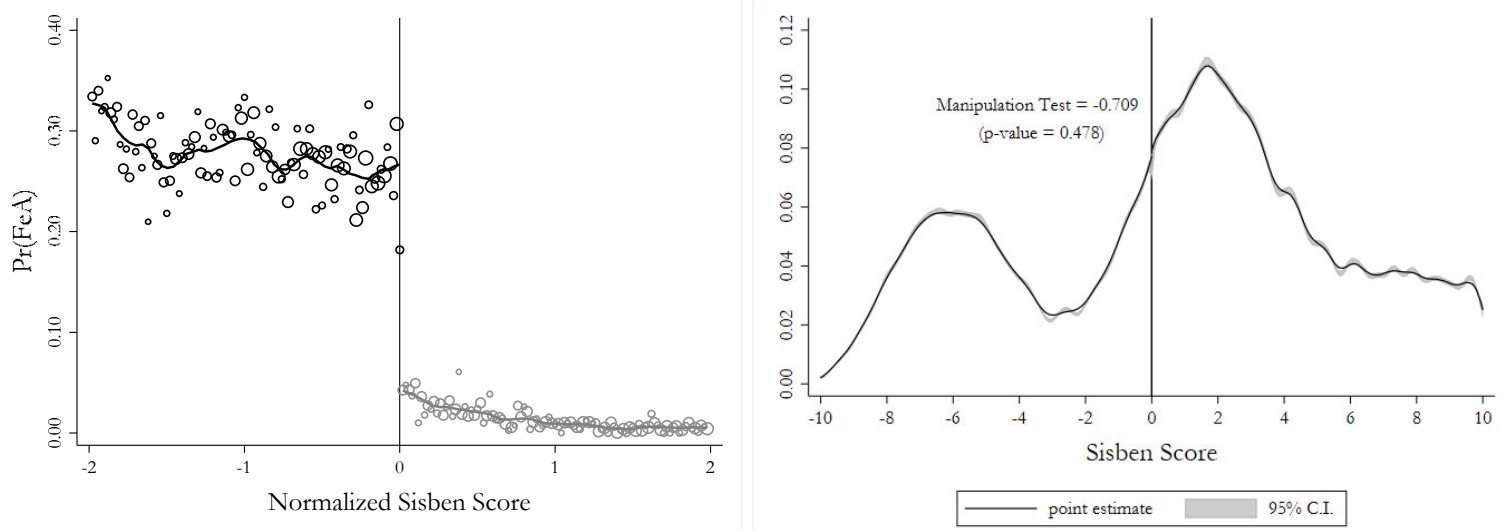

Panel C. Falsification test at score 10

Panel D. Falsification test at score 12
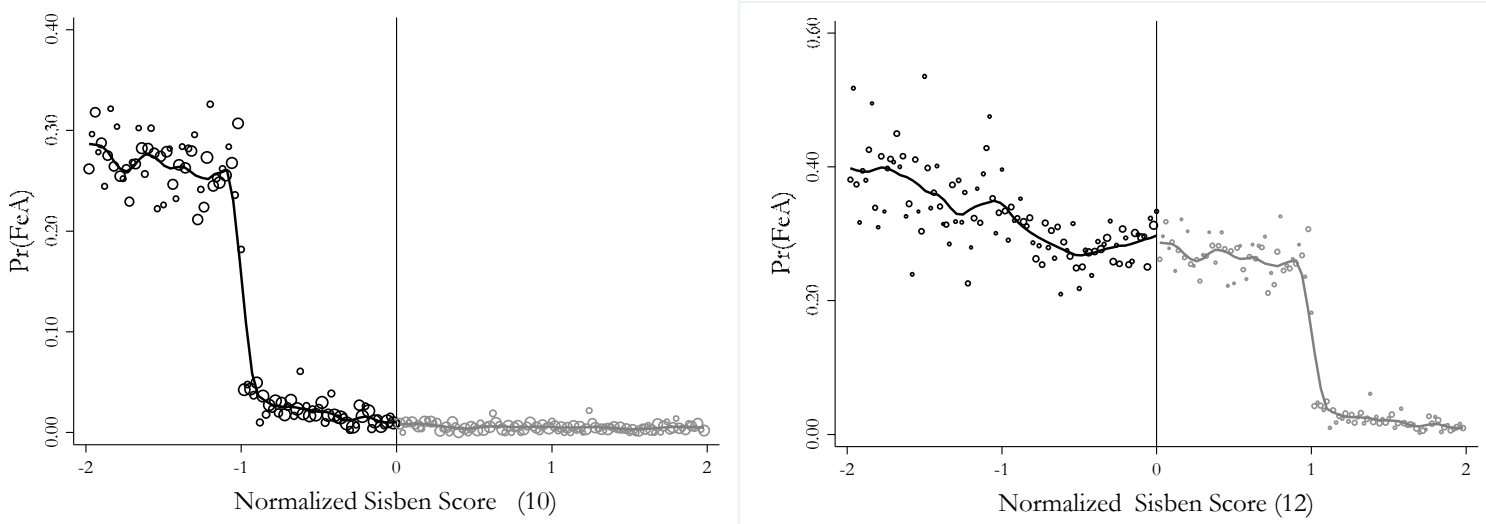

Notes: Panel A, C and D report the proportion of individuals receiving $F e A$ (vertical axis) as a function of the SISBEN-II score (horizontal axis). These figures show the linear fit in the score on either side of the threshold (solid lines) using Kernel-weighted local polynomial smoothing. The size of the circles in all panels is proportional to the number of observations in that cell. Panel A uses as the normalized score the true threshold of 11, while panels $\mathrm{C}$ and $\mathrm{D}$ use as thresholds the scores of 10 and 12, respectively. Panel B shows the manipulation test by Cattaneo, Jansson \& Ma (2018). The test uses as left bandwidth 0.681, right bandwidth 0.498 and includes 42,278 observations.

As previously stated, for the RDD approach to produce valid estimates, individual characteristics at baseline need to change smoothly at the eligibility threshold. While we cannot test that unobservable characteristics change smoothly at the cutoff, we can test for the presence 
of abrupt changes in observed variables at that point. We conduct a balance test using the optimal bandwidth for the whole sample. Table 3 reports estimates for the existence of a discontinuity around the cutoff for the demographic variables. In Table 3 we are testing simultaneously fourteen hypotheses. We thus report both standard single hypothesis p-values as well as those adjusted for multiple hypotheses testing based on the stepdown procedure proposed by Romano and Wolf $(2005,2016)$. Henceforth we refer to the latter as stepdown pvalues. The absence of significant effects reflects that the assignment rule is as good as random assignment of the program.

\section{Table 3. Estimates for the presence of Discontinuity on Demographic variables at the} threshold

\begin{tabular}{lccc}
\hline \multicolumn{1}{c}{ Variable } & \multicolumn{3}{c}{ P-Values } \\
& Coefficient & Standard & RW \\
\hline \hline Gender (women) & -0.005 & 0.395 & 0.980 \\
Individual's age in 2005 & -0.196 & 0.270 & 0.945 \\
Household head's age in 2005 & -0.010 & 0.977 & 0.975 \\
Household head's education in 2005 & -0.116 & 0.251 & 0.955 \\
Percentage of people under 5 and over 60 & 0.024 & 0.113 & 0.723 \\
Homeownership & -0.011 & 0.553 & 0.966 \\
Living in a house/apartment & 0.000 & 0.970 & 0.999 \\
Stratum 1 & -0.013 & 0.297 & 0.952 \\
Home at risk & -0.006 & 0.267 & 0.958 \\
Gas service in the house & 0.002 & 0.767 & 0.994 \\
Sewerage service in the house & -0.014 & 0.126 & 0.739 \\
Aqueduct service in the house & -0.003 & 0.440 & 0.979 \\
Crime in 2005 & -0.001 & 0.533 & 0.989 \\
Years of education in 2006 & -0.144 & 0.040 & 0.388 \\
\hline
\end{tabular}

Notes: The type is an MSE-optimal bandwidth selector (below and above the cutoff) for the RD treatment effect estimator. The local-polynomial is constructed using a triangular kernel function. The variance-covariance matrix is estimated clustering by the score (Lee and Card, 2008). "Standard" refers to single hypothesis p-values. "RW" refers to Romano Wolf $(2005,2016)$ stepdown p-values adjusted for multiple testing accounting for all 14 outcomes. The number of observations corresponds to those in column 1 of Table 2.

The key idea in RDD is that individuals in the neighborhood of the cutoff are as good as randomly assigned in a small neighborhood around the cutoff. However, if some individuals can effectively manipulate the score to ensure they obtain 11 or less and if their ability to do so is outcome relevant (e.g., is correlated with a willingness to complete high school), we can no longer take the allocation to be as good as random. Camacho and Conover (2011) did find some evidence of score manipulation in earlier versions of SISBEN and at scores different from the 
$\mathrm{Fe} A$ eligibility threshold. We present test for score manipulation at the FeA cutoff in SISBENII among eligible households. The manipulation test examines the distribution of the running variables (SISBEN here) around the cutoff and looks for discontinuities. For example, if a substantial proportion of individuals manipulated their score to end up below the cutoff, we should observe a rise in the density to the left of the threshold and a sudden drop to the right (see, Cattaneo, Jansson and Ma, 2018). Figure 1, panel B shows the distribution of individuals at the cutoff, which displays no discontinuities. We thus find no evidence of manipulation of the SISBEN-II score at the cut-off. ${ }^{11}$

Finally, we perform falsification tests by checking for the existence of a discontinuity at scores different to the eligibility rule; they support our previous findings: the only discontinuity in the probability of participating into the program occurs around the score of 11 (See Figure 1, panels $\mathrm{C}$ and $\mathrm{D})$.

Given the corroborative evidence for the identifying assumptions we can be reasonably confident that the impacts we estimate can be given a causal interpretation.

\section{Identifying the long run effects of Familias en Acción.}

We now estimate the effect of Familias en Acción on several outcomes. For men, we consider criminal behavior, measured by arrests, and for women, pregnancy at an age lower than 18; for both sexes we consider dropping out of high school and participation in tertiary education. Incidence of arrests and teen pregnancies are measured in the period from the beginning of the program to December 2015 and December 2016, respectively. We define high-school dropouts individuals who did not have a high-school diploma and were not in school at age 19 by $2017^{12}$ based on administrative records. Finally, we consider whether an individual attended tertiary education by 2016 .

Table 4 contains the impacts estimates using the optimal bandwidth. ${ }^{13}$ Panel A contains the intent to treat estimates, while panel B presents the LATE estimates. The first column reports a reduction in the arrest rate (our measure of crime) of 2.7 percentage points (pp) from a base of $6.2 \%$ for the control group. The estimate is very precise with a stepdown p-value (accounting

\footnotetext{
11 The data driven interval was chosen following the methodology of Calonico, Cattaneo, and Titiunik (2014a) and Cattaneo, Janson and $\mathrm{Ma}$ (2017). We also found similar conclusions using fixed intervals at $(-1,1),(-3,3)$.

12 See Foley, Gallipoli and Green (2014)

$13 \mathrm{We}$ also estimate the outcomes using several alternative windows. The conclusions remain the same.
} 
for all six outcomes in the Table) of 0.026 . Teenage pregnancy ( $2^{\text {nd }}$ column) declines by $2.3 \mathrm{pp}$ from a control mean of $8.4 \%$ with a stepdown p-value of 0.028 . Therefore, both these critical outcomes improve substantially as a result of the program. School dropout declines by 5.8pp for both men and women which is highly significant with a stepdown p-values less of 0.011. Finally, the program caused an increase in tertiary school participation for men by $1.7 \mathrm{pp}$ ( $\mathrm{p}$-value 0.085 ) but not for women.

Table 4. Impacts of Familias en Acción on crime, teenage pregnancy, high school dropout and tertiary education

\begin{tabular}{|c|c|c|c|c|c|c|}
\hline & $\begin{array}{l}\text { Crime } \\
\text { (Men) }\end{array}$ & $\begin{array}{c}\text { Teenage Preg. } \\
\text { (Women) }\end{array}$ & $\begin{array}{c}\text { Dropout } \\
\text { (Men) }\end{array}$ & $\begin{array}{l}\text { Dropout } \\
\text { (Women) }\end{array}$ & $\begin{array}{l}\text { Tertiary } \\
\text { Educ. } \\
\text { (Men) }\end{array}$ & $\begin{array}{l}\text { Tertiary } \\
\text { Educ. } \\
\text { (Women) }\end{array}$ \\
\hline \multicolumn{7}{|l|}{$\begin{array}{l}\text { Panel A: Intention to treat } \\
\text { estimates }\end{array}$} \\
\hline Coefficient & $-0.027 * *$ & $-0.023^{* *}$ & $-0.058^{* * *}$ & $-0.058 * *$ & $0.017^{*}$ & 0.000 \\
\hline Std. Error & $(0.009)$ & (0.008) & (0.017) & (0.017) & $(0.009)$ & (0.010) \\
\hline RW p-value & {$[0.026]$} & {$[0.028]$} & [0.009] & {$[0.011]$} & {$[0.085]$} & {$[0.996]$} \\
\hline \multicolumn{7}{|l|}{ Panel B: LATE estimates } \\
\hline Coefficient & $-0.064 * *$ & $-0.093^{* *}$ & $-0.186 * * *$ & $-0.187 * * *$ & $0.060^{*}$ & -0.002 \\
\hline Std. Error & $(0.024)$ & $(0.036)$ & $(0.046)$ & $(0.053)$ & $(0.029)$ & $(0.033)$ \\
\hline RW p-value & {$[0.042]$} & {$[0.035]$} & {$[0.002]$} & {$[0.007]$} & {$[0.061]$} & {$[0.942]$} \\
\hline Number of Observations & 82,647 & 80,600 & 82,647 & 80,600 & 82,647 & 80,600 \\
\hline Control Mean & 0.062 & 0.085 & 0.616 & 0.504 & 0.119 & 0.146 \\
\hline
\end{tabular}

Notes: *** Significant at the 1 percent level. ** Significant at the 5 percent level. * Significant at the 10 percent level. Stars are associated with Romano and Wolf $(2005,2016)$ stepdown p-values, which are shown in the last row of each panel A and B respectively and account for joint testing of all six hypoteses. We use an MSE-optimal bandwidth selector (below and above the cutoff) for the $\mathrm{RD}$ treatment effect estimator chosen by cross validation. The localpolynomial is constructed using a triangular kernel function. The variance-covariance matrix is estimated clustering by the score (Lee and Card, 2008) and computed based on the bootstrap using 1000 replications. The number of observations reported in the table correspond to the sample size. The effective number of observations used depends on the optimal bandwidth.

The results we report in panel A of Table 4 should be interpreted as Intent to Treat (ITT) long run impacts of the program, as they compare outcomes of individuals just above the eligibility cutoff to those just below. However, as compliance has been low among eligible individuals, we also report the LATE effect of participating in $F e A$ using eligibility as an instrument. One of the key reasons for low take-up of the program was the government budget constraint that led to eligible individuals being denied after funding was exhausted. These estimates are reported in panel B of Table 4. 
The LATE estimates are large and substantial. Crime declines by $6.4 \mathrm{pp}$, teenage pregnancy by $9.3 \mathrm{pp}$, school dropout rates are lower by almost 19pp and college enrollment increases by $6.0 \mathrm{pp}$ for men. These estimates show that the program has substantial long run impacts on compliers.

\section{Discussion and Conclusions}

Welfare programs are an important tool for fighting poverty. Yet they are often evaluated with relatively narrow objectives in mind, such as immediate income support or perhaps improving school attendance through conditionalities. Yet, they may have much more profound and longterm effects through their impact on poverty alleviation and improvements in human capital that they induce. Familias en Acción in Colombia is a case in point: we show here that it had major impacts on non-targeted outcomes that are central to standards of living: it reduces arrests for criminal behavior and teen pregnancies and increases educational attainment. These outcomes can have profound effects on individuals and offer an even stronger justification for welfare programs as essential tools in fighting poverty and improving equal opportunity.

\section{References}

Almond, Douglas, Hillary Hoynes and Diane Schanzenbach (2011). "Inside the War on Poverty: The Impact of Food Stamps on Birth Outcomes" The Review of Economics and Statistics (2011) 93 (2): 387-403

Angelucci, Manuela and Giacomo De Giorgi (2009). "Indirect effects of an aid program: how do cash transfers affect ineligibles' consumption?” American Economic Review 99 (1), 486-508

Attanasio, Orazio, Alice Mesnard (2006). "The Impact of a Conditional Cash Transfer Programme on Consumption in Colombia", Fiscal Studies, Institute for Fiscal Studies, vol. 27(4), pages 421-442, December.

Attanasio,Orazio, Emla Fitzsimons, Ana Gomez, Martha Isabel Gutiérrez, Costas Meghir, and Alice Mesnard (2010). "Children's Schooling and Work in the Presence of a Conditional Cash Transfer Program in Rural Colombia", Economic Development and Cultural Change, 58:2, 181210.

Attanasio, Orazio, Costas Meghir and Ana Santiago (2011): "Education choices in Mexico: using a structural model and a randomized experiment to evaluate Progresa", The Review of Economic Studies 79 (1), 37-66. 
Attanasio, Orazio, Erich Battistin, Alice Mesnard (2012). "Food and Cash Transfers: Evidence from Colombia”, The Economic Journal, Volume 122, Issue 559, March 2012, Pages 92-124.

Attanasio, Orazio, Veruska Oppedisano, and Marcos Vera Hernández, (2015). "Should Cash Transfers Be Conditional? Conditionality, Preventive Care, and Health Outcomes," American Economic Journal: Applied Economics, 7 (2): 35-52.

Attanasio, Orazio and Elena Pastorino (2020): "Non linear Prices in Village Economies", Econometrica 88 (1), 207-263.

Baez, Javier, Adriana Camacho (2011). “Assessing the Long-term Effects of Conditional Cash Transfers on Human Capital: Evidence from Colombia," Documentos CEDE 008900, Universidad de los Andes - CEDE.

Banerjee, Abhijit, Rema Hanna, Benjamin A. Olken, Elan Satriawan and Sudarno Sumarto, (2021): "Food vs. Food Stamps: Evidence from an At-Scale Experiment in Indonesia". Mimeo, https://economics.mit.edu/files/21317.

Barrientos, Armando; Byrne, Jasmina; Villa, Juan Miguel; Peña, Paola (2013). "Social Transfers and Child Protection", Innocenti Working Papers no. 2013-05.

Bottia, M., Cardona Sosa, L., \& Medina, C. (2013). El SISBEN como mecanismo de focalización individual del régimen subsidiado en salud en Colombia: ventajas y limitaciones. Revista De Economía Del Rosario, 15(2), 137-177.

Calonico, S., Cattaneo, M., \& Titiunik, R., (2014a). "Robust Nonparametric Confidence Intervals for Regression-Discontinuity Designs”, Econometrica, 82(6), 2295-2326.

Calonico S, Cattaneo MD, Titiunik R., (2014b). "Robust Data-Driven Inference in the Regression-Discontinuity Design", The Stata Journal.14(4):909-946.

Camacho, A., \& Conover, E. (2011). "Manipulation of Social Program Eligibility", American Economic Journal: Economic Policy, 3(2), 41-65.

Cardona-Sosa, Lina, Carlos Medina (2017). "Impacto de las Transferencias Condicionadas sobre el Mercado de Crédito El caso de Familias en Acción en Colombia” in "Ensayos sobre Inclusión Financiera en Colombia" edited by Cesar Tamayo and Jonathan Malagón. Asobancaria, and BID.

Cattaneo, M. D., M. Jansson, and X. Ma (2017). "Simple local polynomial density estimators", Working paper, University of Michigan.

Cattaneo, Mattias, Michael Jansson, Xinwei Ma (2018). "Manipulation testing based on density discontinuity," Stata Journal, StataCorp LP, vol. 18(1), pages 234-261, March.

Cunha, Jesse (2014). “Testing Paternalism: Cash versus In-Kind Transfers", American Economic Journal: Applied Economics, 6 (2): 195-230. 
Cunha, Jesse M., Giacomo De Giorgi, Seema Jayachandran (2019). “The Price Effects of Cash Versus In-Kind Transfers." The Review of Economic Studies, 86 (1): 240-281.

Departamento Nacional de Planeación, DNP (2008). "Programa Familias en Acción: Impactos en capital humano y Evaluación beneficio-costo del Programa".

Departamento Nacional de Planeación, DNP (2010). "El camino recorrido. Diez años de Familias en Acción". Acción Social y DNP.

Deshpande, Manasi and Michael Mueller-Smith (2021) "Does Welfare Prevent Crime? Criminal Justice Involvement Among Youth Receiving Supplemental Security Income," mimeo presented at the Cowles conference on Labor and Public Finance - Yale 2021.

Egger, Dennis, Johannes Haushofer, Edward Miguel, Paul Niehaus, and Michael W. Walker. (2019). "General equilibrium effects of cash transfers: experimental evidence from Kenya", NBER Working Paper \#26600.

Filmer, Deon, Jed Friedman, Eeshani Kandpal, and Junko Onishi (2018). "Cash Transfers, Food Prices, and Nutrition Impacts on Nonbeneficiary Children”, World Bank Policy Research Working Paper 8377.

Fiszbein, Ariel; Schady, Norbert; Ferreira, Francisco H.G.; Grosh, Margaret; Keleher, Niall; Olinto, Pedro; Skoufias, Emmanuel (2009). "Conditional Cash Transfers : Reducing Present and Future Poverty”, World Bank Policy Research Report. Washington, DC: World Bank.

Foley, Kelly, Giovanni Gallipoli, David A. Green (2014). "Ability, Parental Valuation of Education, and the High School Dropout Decision", Journal of Human Resources, University of Wisconsin Press, vol. 49(4), pages 906-944.

Hahn J., Todd P. E. and van der Klaauw W. (2001) "Identification and Estimation of Treatment Effects with a Regression-Discontinuity Design”, Econometrica 69: 201-209

Hoynes, Hillary, Diane Schanzenbach and Douglas Almond (2016) "Long-Run Impacts of Childhood Access to the Safety Net", American Economic Review vol. 106, no. 4, April 2016.

Imbens, Guido W. and Thomas Lemieux (2008). "The regression discontinuity design — theory and applications", Special Issue, Journal of Econometrics 142, no. 2: 611-614.

Lee, David S. \& Card, David, 2008. "Regression discontinuity inference with specification error," Journal of Econometrics, Elsevier, vol. 142(2), pages 655-674, February.

Lochner, Lance and Moretti, Enrico, (2004). "The Effect of Education on Crime: Evidence from Prison Inmates, Arrests, and Self-Reports," American Economic Review, American Economic Association, vol. 94(1), pages 155-189, March.

Machado, Daiane and Williamson, Elizabeth and Pescarini, Julia and Rodrigues, Laura and Alves, Flavia J. O. and Araújo, Luis and Ichihara, Maria Yury Travassos and Araya, Ricardo and Patel, 
Vikram and Barreto, Mauricio L., (2021): "The Impact of a National Cash Transfer Programme on Reducing Suicide: A Study Using the 100 Million Brazilian Cohort”, The Lancet, forthcoming.

Molina-Millan, Teresa \& Barham, Tania \& Macours, Karen \& Maluccio, John A. \& Stampini, Marco, (2016). "Long-term Impacts of Conditional Cash Transfers in Latin America: Review of the Evidence,” IDB Publications (Working Papers) 7891, Inter-American Development Bank.

Núñez, Jairo, Orizel Llanos, Patricia Heredia, Guillermo Rivas, Zandra Pedraza, Marta Villegas, Andrés Bateman, Carlos Castro, Carlos Castaneda (2011). "Evaluación del programa familias en acción en grandes centros urbanos". Centro Nacional de Consultoría.

Romano, Joseph P. \& Wolf, Michael (2005). "Exact and approximate stepdown methods for multiple hypothesis testing" Journal of the American Statistical Association, 100(469):94-108.

Romano, Joseph P. \& Wolf, Michael (2016). "Efficient computation of adjusted p-values for resampling-based stepdown multiple testing," Statistics \& Probability Letters, Elsevier, vol. 113(C), pages $38-40$.

Schultz, T. P. (2004), "School Subsidies for the Poor: Evaluating the Mexican Progresa Poverty Program", Journal of Development Economics, 74, 199-250.

Thistlewaite, D and D. Campbell (1960). "Regression Discontinuity Analysis: An Alternative to an ex-post facto experiment”, Journal of Educational Psychology 51, 309-317.

Todd, Petra, E., and Kenneth I. Wolpin (2006). "Assessing the Impact of a School Subsidy Program in Mexico: Using a Social Experiment to Validate a Dynamic Behavioral Model of Child Schooling and Fertility", American Economic Review, 96 (5): 1384-1417.

Van der Klaauw, W., (2002). "Estimating the Effect of Financial Aid Offers on College Enrollment: A Regression-Discontinuity Approach”, International Economic Review, 43(4), 12491287.

Villa, Juan Miguel (2018). "The continuous treatment effect of an antipoverty program on children's educational attainment: Colombia's Familias en Accion", Review of Development Economics, Wiley Blackwell, vol. 22(3), pages 1239-1262, August. 